\title{
TOPICS 表面・界面での環境応答性グラフトポリマー
}

高分子材料の大きな特徵のひとつは, 金属・セラミ ックス材料と比べて大きなフレキシビリティをもって いることであり，特にその表面では，接触する媒体と の相互作用を通して界面自由エネルギーを最小にする ように，構造・配向・モルホロジーなどを再構成(リス トラクチャリング) することが可能となる。このこと は生医学材料分野への応用を含めた新しい表面・界面 機能をもつ高分子素材を設計するに当たり特に考慮す べき課題と思われる。

われわれは多相系高分子素材の表面および界面のミ クロ相セグメント単位の環境応答性に関して，一連の 構造明確なグラフト共重合体を合成し，検討を進めて いる ${ }^{1), 2)}$.ここでは多相系高分子表面・界面のユニーク な環境応答について，ポリウレタンーポリシロキサン グラフト共重合体を例に紹介したい ${ }^{3)}$ 。このグラフト 共重合体は，分子量のそろった末端ジオール型ポリジ メチルシロキサンマクロモノマーを用いた重付加反応 によって得られるもので，ポリシロキサン鎖長，シロ キサン含量の制御が可能である。また，ポリシロキサ ンはその高いフレキシビリティ，および低い表面エネ ルギーのため，ポリウレタンと組み合わせると容易に 表面濃縮層を形成すると予想され，表面性状の環境応 答を観測するのに適したものと思われる。ささらにポリ ウレタンーポリシロキサン型多相系素材は, 血液適合 性に優れたカルジオサンのモデルとしても興味深い.

はじめに，このグラフト共重合体の空気中での表面 構造を XPS (X線光電子分光分析) を用いて解析した 結果, 試料のポリシロキサン鎖長扔よびシロキサン含 量によって, 表面のポリシロキサン濃縮層の厚さが, 約 $100 \AA$ 以上〜約 $20 \AA$ 以下の範囲に変化することが認 められた。すなわち,グラフト共重合体中のポリシロ キサン鎖長およびシロキサン含量をコントロールする ことによって, 試料膜表面のポリシロキサン濃縮層の 厚さを制御することが可能となる。

次に，このグラフト共重合体試料膜を水中 $\left(20^{\circ} \mathrm{C}\right)$ に浸漬して空気泡に対する接触角を時間を追って測定 したところ，シロキサン含量の小さいグラフト共重合 体 $(○$ ，○）では，図1に示すように当初のポリシロ キサンホモポリマー $(\triangle)$ に近い值からポリウレタン ホモポリマー $(\square)$ に近い值へと 3 時間程度のタイム スケールで変化していくのが認められ, 界面で接触す る媒体の変化 (空気 $\rightarrow$ 水) に伴う表面構造の変化を示 唆している.一方, ポリシロキサン鎖長が長く, シロ

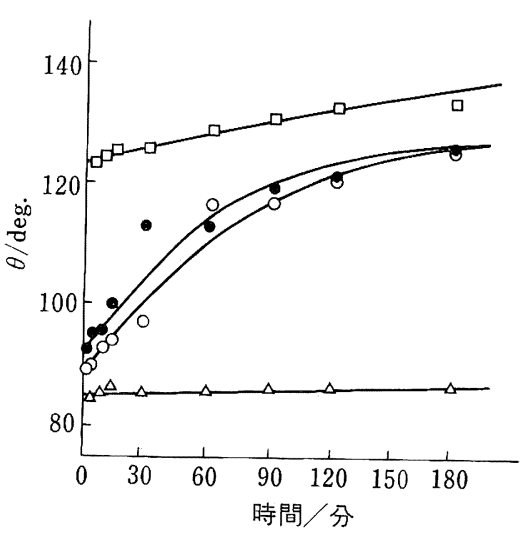

図 1 グラフト共重合体表面の接触媒体による構造变化

キサン含量の多い試料では 24 時間浸漬後でも, 接触 角に大きな変化はみられなかった。すなわち，このグ ラフト共重合体表面の環境応答性は, 試料表面のポリ シロキサン濃縮層の厚さによって決定され, 約 $100 \AA$ 以下の場合に生じていることが示される.

このような高分子素材表面の環境応答性は，生体成 分との水溶液中での相互作用とも密接に関連している ものと考えられ，実際，牛血清アルブミンの吸着試験 の結果, シロキサン含量の多い試料への吸着量はポリ シロキサンホモポリマーへのそれとほとんど変わら ず，一方，シロキサン含量の少ない試料では，ポリウ レタンホモポリマーへのそれに近づく.これは先に述 べた接触角測定の結果と合致し,このグラフト共重合 体表面での環境応答性構造変化を支持している.

さらに, ここで述べた環境応答性構造変化が可逆的 であることが，試料を水中に浸漬する前と，水中から 回収し再び乾燥したときとの空気中での水滴に対する 接触角が一致することから示される。

\section{文献}

1) Y. Tezuka, A. Fukushima, S. Matsui, K. Imai : $J$. Colloid Interface Sci., 114, 16 (1986)

2) Y. Tezuka, K. Imai : Chemically Modified Surfaces in Science and Industry, ed., D.E. Leyden, W.T. Collins, Gorden \& Breach (1988) p.643

3）手塚育志, 小野達也, 今井清和: Polymer Preprints, Japan, 37 (6), 1466 (1988)

手塚 育志 Yasuyuki Tezuka （長岡技術科学大学 化学系・助手, 工博, Dr. Sci., 専門=高分子合成, 高 分子反応) 